PROCEDIA

Studi Kasus dan Intervensi Psikologi

ISSN:2302-1462

Volume 7(1) 1-12, Januari 2019

DOI: $10.22219 /$ procedia.v7i1.12976

\title{
Teknik penguatan positif untuk anak dengan keterbatasan intelektual
}

Dian Nur Andriani Eka Setiawati, Universitas Muhammadiyah Malang, Malang, Indonesia

Korespondonesi:

Dian Nur Andriani Eka Setiawati, Universitas Muhammadiyah Malang,

diannurandrianiekasetiawati@gmail.com

\section{Riwayat artikel \\ Naskah diterima: \\ $08 / 09 / 2018$}

Revisi diterima:

$11 / 11 / 2018$

Naskah disetujui:

$11 / 12 / 2019$

\begin{abstract}
Abstrak
Intelektual disabilitas (ID) adalah gangguan pada masa perkembangan anak dari sisi akademik dan keterampilannya dalam aktivitas sehari-hari. Klien $\mathrm{T}(\mathrm{P} / 7 \mathrm{thn})$, dikeluhkan oleh sekolah kesulitan dalam membaca, berhitung, sulit konsentrasi, kurangnya perawatan diri, kurang mampu memahami perkataan, serta marah dan menangis jika keinginannya tidak dipenuhi. Kedua orang tua klien cenderung memanjakan dan tidak memberikan perhatian lebih dalam akademik karena ayah klien yang bekerja dan ibu klien yang juga kesulitan dalam akademik. Metode wawancara, observasi, pemberian alat tes Binet serta Vineland Social Maturity Scale diberikan untuk mengetahui tingkat kecerdasan dan kemampuan klien. Hasil asesmen menunjukan IQ klien yaitu 64 termasuk kategori mild retardation mental dalam tes binet, dan memiliki kemandirian serta kemampuan yang rendah dalam tes vineland. Untuk itu pemberian intervensi dalam bentuk penguatan positif diberikan agar klien memiliki keterampilan yang mandiri seperti mandi, makan, serta berpakaian sendiri. Intervensi ini diberikan dalam 7 sesi, yang juga memiliki sesi psikoedukasi untuk kedua orang tua klien mengenai keadaan klien dan bagaimana cara memperlakukan klien. Dari hasil intervensi, klien sudah mulai bisa mandi, mengambil makanan, serta berpakaian sendiri. Klien senang mendapatkan pujian dan uang jajan dari kedua orang tuanya karena mampu melakukan tugasnya. Kata kunci: Intelektual disabilitas (ID), behavior, penguatan positif, anak.
\end{abstract}

\section{Latar Belakang}

Orang tua memiliki harapan untuk mendapatkan anak-anak yang sehat baik jasmani maupun mentalnya, namun tidak semua harapan orang tua menjadi kenyataan. Orang tua harus menerima apapun kondisi anak yang dilahirkan dan diharuskan tetap memikirkan kelangsungan 
hidup anaknya tersebut, walaupun memiliki anak yang dilahirkan menderita gangguan fisik maupun mental. Namun ketika harapan dan mimpi indah tersebut tidak menjadi kenyataan, muncul rasa kecewa yang mendalam bercampur sedih, bingung, marah, putus asa, tidak bergairah, dan tidak berdaya sampai mati langkah. Bahkan cinta kasih dan sayang kepada sang anak berubah menjadi kebencian, muncul rasa malu, tidak percaya diri, berdosa, saling menyalahkan contohnya orang tua yang memiliki anak dengan keadaan berkebutuhan khusus.

Anak berkebutuhan khusus dibagi menjadi dua jenis yaitu anak berkebutuhan khusus pada fisik dan anak berkebutuhan khusus pada psikis. Anak dengan intelektual disabilitas (ID) atau yang sering dikenal dengan nama retardasi mental menjadi salah satu contoh anak yang harus diberikan perhatian yang khusus. Walaupun ada penggantian istilah penyebutan, American Association on Intellectual and Developmental Disabilities (AAID, dahulu disebut American Association of Mental Retardation, AAMR) menyatakan bahwa tidak ada perbedaan antara definisi ID dan RM (Ishartiwi, 2010). Anak dengan DI merupakan anak yang memiliki hambatan dalam kognitif, afektif, psikomotorik, maupun sosial. Secara kognitif, anak dengan ID memiliki fungsi intelektual di bawah rata-rata (Albrecht, Seelman, \& Bury, 2001).

Intelektual disabilitas menunjukan bahwa individu yang mengalami hambatan mental mencakup aspek inteligensi, sosial, dan fungsi mental. Faktor yang menyebabkan hal tersebut tidak dapat dilepaskan dari faktor tumbuh kembang anak, sedangkan faktor yang paling besar adalah genetik yang menurun dari orang tua ke anak, yaitu kelainan kromosom yang menjadi bawaan anak. Selain itu lingkungan juga menjadi faktor anak mengalami hambatan mental dilihat bagaimana situasi dan lingkungan anak saat tumbuh kembang, lingkungan yang baik akan membantu anak dalam konteks sosialnya untuk dapat berinteraksi (Sularyo, 2000).

Seseorang akan dikatakan menderita ID, jika ia memiliki IQ di bawah 70 bersamaan dengan keterbatasan fungsi adaptif. Keterbatasan fungsi adaptif dapat dinilai dari tiga area kemampuan, yaitu konseptual, sosial, dan praktis yang diperlukan seseorang dalam menjalankan kehidupan sehari-hari. Area konseptual meliputi keterampilan dalam berbahasa, membaca, menulis, matematika, penalaran, pengetahuan, dan memori. Area sosial meliputi empati, peniliaian sosial, dan kemampuan komunikasi interpersonal, sedangkan area praktis meliputi kemampuan perawatan diri. Untuk menilai ada tidaknya keterbatasan fungsi adaptif, harus terdapat defisit yang bermakna pada paling sedikit satu dari ketiga area tersebut. Hal ini menunjukkan bahwa tiap-tiap penderita ID memiliki pola keterbatasan yang bervariasi dan tidak selalu memiliki defisit pada ketiga area.

Dua dari masalah utama pembelajaran individu dengan ID adalah kesulitan dengan kemampuan bahasa dan kognitif atau sosial-emosional pengaturan diri (Borkowski, Carothers, Howard, Schatz \& Farris, 2007). Selain itu inteligensi pada anak ID yang berada di bawah rata-rata menyebabkan anak akan kesulitan dalam memahami, berkomunikasi dan keterampilan diri yang akan membuat anak bergantung pada orang lain, seperti tidak mampu melakukan pekerjaan sehari-hari yaitu mandi, makan, berpakaian sehingga tidak berfungsi secara sosial (Saputro, 2014). Kurangnya keterampilan pada bantu diri membuat anak menjadi kurang mandiri, Chaplin (1993) mendefinisikan kemandirian sebagai suatu konsisi dimana seseorang tidak tergantung kepada orang lain.

Intelektual disabilitas bukanlah penyakit melainkan gangguan yang terjadi di masa perkembangan anak, untuk itu intervensi harus diberikan kepada anak dengan ID agar anak mampun memiliki keterampilan dan kemandirian yang akan berguna bagi anak kedepannya. Terapi behavior menjadi salah satu upaya bagi anak dengan ID untuk dapat melatih kemandirian dirinya karena merupakan terapi yang sederhana untuk melatih kemampuan dasar (Corey, 1999). Hal ini sesuai dengan penelitian yang dilakukan oleh Medeiros (2015) yang menjelaskan bahwa individu dengan intelektual disabilitas berfungsi untuk menghasilkan perilaku individual pada tingkat anteseden atau konsekuen menjadi sangat baik dalam mengurangi perilaku masalah 
dan meningkatkan perilaku adaptif. Pentingnya fungsi diri sebagai keberhasilan memotivasi di lihat pada bagaimana dukungan lingkungan, faktor biologis, faktor sosial, atau kognitif yang dapat mempengaruhi efektivitas konsekuensi yang digunakan dalam teknik pengkondisian operan selama perilaku modifikasi (Langthorne \& McGill, 2009).

\section{Metode Asesmen}

Asesmen untuk penegakan diganosa yang tepat dilakukan melalui serangkaian metode antara lain wawancara, observasi dan tes psikologi. Wawancara dilakukan terhadap klien dan juga keluarga untuk memperoleh informasi lebih mendalam tentang riwayat permasalahan yang klien alami. Observasi dilakukan untuk pemeriksaan status mental klien dan untuk memperoleh informasi perilaku dan aktivitas klien selama dirumah maupun di sekolah. Tes psikologis yang digunakan mencakup tes inteligensi yaitu tes Binet untuk mengetahui kapasitas intelektual klien. Penggunaan tes ini bertujuan untuk mendukung data observasi, diduga klien mengalami disabilitas intelektual, karena kemampuan klien pada saat observasi terlihat tidak sesuai dengan umurnya, maka tes Binet yang berfungsi untuk mengetahui sejauh mana IQ yang dimiliki serta umur kematangan mental dari klien, dapat mengklasifikasikan (secara potensial) kemampuan intelektual klien, sehingga tidak salah dalam memberikan intervensi kepada klien.

Selain Binet, tes Vineland Social Marturity Scale (VSMS) diberikan untuk melihat keterampilan bantu diri klien yaitu kemandirian dan kematangan sosial. Tes VSMS diartikan sebagai ukuran dari kemasakan sosial yang disusun oleh Edgar A. Doll, kemudian dikembangkan di Traing school, Vineland-New Jersey. Tes ini terdiri dari 117 item, pada setiap item dipilih sebagai mewakili aspek-aspek dari kemampuan sosial (Supriyono, 2010), seperti SHG (Self Help General), C (Communication), SHE (Self Help Eating), L (Locomotion), SHD (Self Help Dressing), S (Socialization) SD (Self Direction) dan O (Occupation).

\section{Presentasi Kasus}

Klien dengan inisial $\mathrm{T}$ adalah seorang anak perempuan yang berusia 7 tahun, klien duduk di bangku kelas $1 \mathrm{SD}$, seharusnya klien sudah duduk di kelas 2 SD namun karena kemampuan yang jauh di bawah anak-anak di kelasnya akhirnya klien tidak dinaikan ke kelas 2 dan tetap di kelas 1. Klien merupakan anak tunggal, ayah klien merupakan seorang buruh, sedangkan ibu klien hanya ibu rumah tangga. Karena ayah klien yang bekerja dari pagi hingga sore, waktu bersama klien hanya malam seperti memperhatikan klien belajar tanpa membantu anak untuk belajar, sedangkan ibu klien yang ada di rumah juga tidak dapat mengajarkan klien karena status pendidikan ibu yang rendah sulit berbahasa Indonesia dan tidak bisa baca dan menulis. Latar belakang pendidikan yang rendah kedua orang tua klien juga menjadi salah satu faktor kurangnya kemampuan klien.

Riwayat kehamilan ibu klien terbilang normal dan tidak mengalami permasalahan dalam masa kehamilan hingga melahirkan, usia kehamilan ibu klien juga termasuk matang yaitu pada usia dewasa 32 tahun. Kedua orang tua klien menikah pada usia ayah klien 29 tahun dan ibu klien berusia 20 tahun selisih 9 tahun, butuh waktu 12 tahun untuk kedua orang tua klien memiliki anak. Oleh karena itu klien sangat disayang dan dimanjakan karena merupakan anak satu-satunya.

Klien hingga saat ini tidak dapat membaca, hafalan alfabet hanya hinga huruf A hingga $\mathrm{D}$, sedangkan hitungan hanya bisa 1 hingga 10 namun belum bisa penambahan maupun pengurangan, pekerjaan rumah yang diberikan dari sekolah dikerjakan oleh klien namun semua hasil yang klien kerjakan salah, di kelas klien juga terkadang asik sendiri dan hanya bisa fokus dalam beberapa menit kemudian klien hanya sibuk sendiri seperti mencoret-coret buku atau mengajak teman mengobrol. Secara sosial klien termasuk baik karena mampu menjalin pertemanan, dapat berbicara dengan lancar namun penguasaan kosa kata klien masih sedikit. 
Aktivitas klien di rumah masih sangat berfokus pada ibu klien, mandi dan berpakaian masih dibantu oleh ibu klien, dilihat dari sisi kemandirian klien selalu bergantung pada ibunya. Secara motorik klien mampu untuk melakukan aktivitas perawatan diri, namun karena tidak diberikan stimulasi yang baik sehingga klien terbiasa untuk dibantu. Hal ini terjadi karena tidak adanya kesempatan yang diberikan oleh kedua orang tua kepada klien yang beralasan bahwa klien merupakan anak satu-satunya dan memerlukan waktu yang cukup lama untuk klien melakukan hal tersebut sendiri. Kedua orang tua klien mengatakan bahwa sebenarnya klien mampu melakukan mandi dan berpakaian sendiri karena sudah pernah diajarkan, namun karena klien terlalu lama melakukannya maka klien tidak lagi dibiarkan melakukannya sendiri sehingga selalu dibantu oleh ibu klien.

Klien sering menangis dan berontak ketika ada kemauannya yang ingin dituruti seperti jajan. Hal tersebut sering terjadi saat ibu klien menjemput di sekolah, selama perjalanan pulang klien akan menangis dan berontak untuk meminta dibelikan jajan. Jika tidak diberikan, klien akan memukul ibu klien dan ibu klien tidak pernah memarahi klien karena hal tersebut. Alasan ekonomi juga menjadi alasan ibu klien membatasi permintaan klien.

Kemampuan serta kapasistas intelektual klien dikonfirmasi dengan menggunakan tes Binet yang diberikan di rumah klien. Entry tes dilakukan pada usia 6 tahun karena klien berusia 7 tahun, pada saat entry klien langsung celling atau salah semua, klien dapat menjawab namun tidak dapat memenuhi skor yang ditentukan. Sedangkan basal klien pada usia 5 tahun, yaitu 1 tahun di atas celling klien. Secara verbal kosa kata klien sangat minim, setiap pertanyaan selalu dijawab dengan kata "bermain" klien tidak mampu memahami pertanyaan yang diberikan. Dari soal-soal yang ada pada Binet klien kurang mampu dalam menjelaskan arti dari sebuah kata, kurang mampu menjelaskan perbedaan atara dua objek yang berbeda, kurang teliti dalam melihat kekurangan sebuah objek, lemah dalam hitungan pengurangan, kurang mampu dalam menganologikan objek yang berlawanan, serta mengarahkan arah. Namun klien mampu melengkapi gambar, melipat kertas, menjelaskan definisi, menggambar kembali bentuk segi empat, mencari kesamaan dari objek-objek walaupun kemampuan yang klien miliki setara dengan anak usia 5 tahun. Dari hasil tes diketahui bahwa klien memiliki IQ 64 yang termasuk dalam kategori Mild Mental Retardation.

Tes Vineland Social Maturity Scale (VSMS) juga diberikan pada klien untuk melihat tingkat kemampuan klien dalam bantu diri, kemandirian serta kematangan emosi klien. Dari hasil tes VSMS di ketahui bahwa klien memiliki Self Help General (SHG) atau kemandirian umum yang kurang khususnya dalam bentuk memahami waktu ke sekolah. Dari aspek Self Direction (SD) atau kemandirian dalam mengatur diri seperti menentukan memakai baju yang dikenakan atau berbelanja sendiri sangat kurang. Aspek Locomotion (L) atau kemandirian dalam bergerak seperti pergi dan pulang sekolah sendiri, klien masih diantar jemput oleh ibunya. Aspek Self Help Eating (SHE) atau kemandirian dalam makan dan minum juga sangat kurang klien masih membutuhkan bantuan ibunya untuk mengambil peralatan makan dan mengambil makanan, klien juga masih disuapi saat makan. Aspek Occupation $(\mathrm{O})$ atau pekerjaan sangat kurang bahkan klien belum mampu melakukannya seperti membantu pekerjaan rumah seperti mencuci piring, merapikan tempat tidur maupun membantu membersihkan rumah. Aspek Socialization (S) pada klien terlihat klien cukup mampu membangun relasi teman sebayanya, klien mampu mencari teman, bermain ke rumah teman tanpa membutuhkan bantuan. Aspek Self Help Dressing (SHD) atau kemandirian dalam berpakaian klien kurang mampu berpakaian sendiri seperti memilih atau mengambil baju, memakai baju, serta memakai sepatu sendiri klien masih membutuhkan bantuan ibu klien. Aspek terakhir yaitu aspek Communication (C) atau komunikasi klien mampu bersosialisasi namun dalam segi kekayaan kosa kata klien kurang (Supriyono, 2010). 
Berdasarkan uraian asessmen yang telah dijelaskan klien termasuk anak yang memiliki Intellectual disability mild F70 (DSM V), adanya kendala pada keterampilam dalam aktivitas keseharian, kemampuan pemahaman dan minumnya kosa kata. Namun dalam sosial klien termasuk baik karena dapat menjalin hubungan teman sebaya, secara fisik klien tidak jauh berbeda dengan anak normal pada umunya dapat berbicara lancar namun minim akan pembendaharaan kata, sulit menarik kesimpulan, untuk dapat memahami maksud pembicaraan. Perkembangan kognitif klien yang lambat membuat perkembangannya bersifat trial dan eror yang berbeda dengan anak normal yang memahami konsep problem solving (Feist \& Feist, 2009). Anak intellectual disability ringan mampu menyesuaikan diri dengan lingkungan sosial yang lebih luas, mampu melakukan adaptasi sosial di lingkungan terdekat, mampu mengurus diri namun masih di bawah pengawasan orang tua.

Menurut Skinner individu dapat berinteraksi dengan lingkungannya, menerima penguatan positif atau negatif dari tingkah lakunya (Alwisol, 2009). Skinner berpendapat bahwa perilaku yang muncul dapat terjadi karena adanya pembiaran, tidak mendapat kesempatan yang memunculkan proses belajar yang salah (Alwisol, 2009). Hal ini sesuai dengan keadaan klien yang tidak diberikan kesempatan untuk melakukan hal tersebut oleh kedua orang tuanya sehingga menjadi kebiasaan bagi klien untuk bergantung kepada kedua orang tuanya sehingga tidak mandiri. Dengan keadaan klien yang memiliki kemampuan intelektual dan kognitif dalam kategori mental retardasi maka demikian, klien harus diberikan intervensi yang sesuai dengan kemampuan klien yaitu intervensi yang berbasis behavior atau terapi perilaku untuk dapat mengembangkan kemandirian klien dalam sehari-hari melalui penguatan positif.

Penguatan positif diberikan untuk memperbaiki proses belajar yang salah pada klien yang memahami bahwa semua yang klien inginkan akan dibantu dan diberikan oleh orang tuanya sehingga kemandirian klien tidak berkembang sesuai dengan tahap perkembangan klien yang membuat klien terus menerus bergantung kepada orang tuanya. Dinamika terbentuknya perilaku klien yang tidak dapat mengembangkan keterampilan kemandiriannya dalam mengurus diri sendiri dijelaskan melalui model operant conditioning yang memandang bahwa suatu perilaku muncul karena adanya proses pembelajaran yang pada umumnya terjadi karena suatu efek yang mengikuti suatu respon (law of effect) (Feist \& Feist, 2009). Dengan penguatan positif diharapkan klien mampu memahami proses belajar yang lebih baik yaitu dengan memberikan penguatan, klien akan mampu mengembangkan keterampilannya dalam kemandirian karena terus menerus diberikan penguatan dari kedua orang tuanya sehingga menjadi pembiasaan bagi klien untuk dilakukan terus menerus.

\section{Diagnosis dan Prognosis}

\section{Diagnosis}

Hasil diagnosis klien telah memenuhi diagnostic DSM-5 pada gangguan intellectual disability (ID) dengan kategori Mild atau ringan (F70) yang terjadi pada masa perkembangan anak dengan permasalahan kurangnya keterampilan anak dalam kemandirian (American Psychiatric Association, 2013). Klien memiliki IQ 54 yang termasuk dalam kategori ID mild dengan rentang IQ 55-70. Selain itu klien juga memiliki keterbatasan fungsi konseptual meliputi keterampilan dalam berbahasa membaca, menulis, matematika, penalaran, pengetahuan dan memori. Secara sosial cukup baik dan memiliki kemampuan interpersonal, namun memiliki keterbatasan dalam kemampuan kemandirian

\section{Prognosis}

Prognosis dibuat untuk melihat bagaimana tingkat kesembuhan pada klien baik atau buruk, dari hasil assesmen diketahui bahwa prognosis positif karena adanya motivasi anak untuk diajak bekerja sama begitu pula dengan kedua orang tuanya, ayah klien juga mulai meluangkan waktu 
lebih banyak untuk memberikan perhatian saat anak belajar atau melakukan aktivitas di rumah. Lingkungan sekolah klien juga yang mendukung dengan berusaha untuk memahami keadaan klien. Tipe ID yang dimiliki klien termasuk kategori ringan juga membuat prognosis baik karena secara sosial klien masih mampu membentuk interkasi sosial dengan teman-temannya, serta motorik dan sensorik klien yang terlihat seperti pada anak normal umumnya.

\section{Intervensi}

Desain intervensi yang digunakan pada kasus ini berupa terapi behavior digunakan sebagai penerapan sistematis prinsip-prinsip belajar pada perubahan perilaku ke arah cara-cara yang lebih adaptif dan menjadikan lebih mandiri (Corey, 2013). Latipun (2015) berpendapat bahwa terapi behavior yaitu suatu terapi kehidupan tanpa mengalami kesulitan atau hambatan perilaku yang dapat membuat ketidakpuasan dalam jangka panjang, atau mengalami konflik dengan lingkungannya. Intervensi behavior dapat dilakukan pada klien yang berusia 7 tahun dengan kategori anak dan juga memiliki keterbatasan dalam intelektual klien yang rendah karena fungsi kognitif klien yang tidak bisa berkembang sesuai dengan usianya saat ini, yang terlihat dari perilaku klien.

Tujuan pemberian intervensi ini untuk menciptakan kondisi baru bagi proses belajar pada klien, dengan dasar bahwa perilaku dapat di pelajari termasuk perilaku yang maladaptif sehingga memunculkan target yang diingikan yaitu klien dapat memunculkan kemandirian dalam dirinya dalam bentuk mandi sendiri tanpa dimandikan, makan sendiri dengan mengambil lauk sendiri dan tidak disuapi, memakai baju sendiri yang bertujuan untuk menciptakan kondisi baru bagi proses belajar dan membantu klien untuk dapat meninggalkan respon lama (Wilis, 2007).

Terapi perilaku yang diberikan dengan teknik penguatan sebagai, agar anak dapat melakukan perilaku tersebut secara berulang-ulang (Wilis, 2007). Penguatan memiliki peran sebagai motivasi anak untuk tetap melakukan perilaku baru. Jenis penguatan yang digunakan yaitu primary reinforcer atau penguatan tidak terkondisi, yaitu saat klien mau mengerjakan tugas atau belajar maka klien akan diberikan hadiah. Yang kedua yaitu secondary reinforcer atau penguatan terkondisi yang berkaitan dengan tingkah laku jika anak dapat mandi sendiri maka akan diberikan pujian. Yang terakhir adalah contingency penguatan yaitu tingkah laku yang kurang menyenangkan digunakan sebagai syarat agar anak mau melakukan misalnya mengerjakan tugas terlebih dahulu baru klien boleh bermain (Wilis, 2007). Adapun sesi-sesi intervensi yang dilakukan didasarkan pada langkah yang dikemukakan Komalasari \& Gantina (2011) sebagai berikut.

Sesi pertama: Building raport. Melakukan building raport pada klien dengan menanyakan apa saja kegiatan klien saat berada di rumah maupun di sekolah, adakah kegiatan yang akan klien lakukan sendiri tanpa dibantu atau harus diawasi orang tua klien, membangun raport dengan klien agar klien dapar merasa nyaman. Klien menceritakan bahwa klien selalu dibantu oleh orang tuanya makan, mandi, berangkat ke sekolah semua dilakukan dengan bantuan kedua orang tuanya.

Sesi kedua: Kontak kerja dan pengenalan terapi. Melakukan kontrak kerja dengan orang tua klien dengan akan diadakanya terapi sebagai solusi atas permasalahan yang klien alami dan keluhkan kemudian menjelaskan prosedur yang akan diberikan pada klien dan manfaat terapi yang akan diberikan. Dalam tahap ini terapis menjelaskan kepada kedua orang tua klien apa yang akan diberikan kepada klien, kedua orang tua setuju untuk memberikan terapi kepada klien dan menentukan reward apa yang akan diberikan kepada klien yaitu berupa pujian dan juga uang jajan yang disesuaikan dengan keadaan orang tua klien.

Sesi ketiga: Spesifikasi dan penetapan tujuan.Mengidentifikasi perilaku klien serta melihat hambatan yang kemungkinan klien hadapi saat menentukan target perilaku yang diinginkan seperti perilaku klien untuk mandiri. Dalam mengidentifikasi perilaku yang diinginkan 
disimpulkan dari pernyataan klien yang menyatakan bahwa dirinya selalu dibantu oleh kedua orang tuanya saat mandi maupun berpakaian, kedua orang tua klien juga menentukan perilaku sebagai target perilaku yang diinginkan dari hal-hal kecil dan sederhana serta sebelumnya telah dipelajari oleh klien namun tidak biasa dilakukan oleh klien seperti makan, mandi dan berpakaian. Kegiatan mandi di nilai 2 kali dalam sehari yaitu mandi pagi dan sore, makan dinilai juga 2 kali makan siang dan malam, kecuali pagi karena pagi klien terbiasa sarapan di sekolah, sedangkan untuk berpakaian juga di jadwalkan 2 kali yaitu saat akan ke sekolah dan pergi mengaji.

Orang tua klien mengakui bahwa kadang tidak tega membiarkan anaknya melakukan hal tersebut sendiri, kemudian hambatan saat anak menangis dan marah jika tidak diikuti kemauannya. Kedua orang tua sepakat bahwa akan hanya mengawasi dan mengarahkan tanpa membantu, saat klien menangis dan marah kedua orang tua hanya akan memberikan penjelasan dan menangkan namun tidak membantu dan hanya membujuk klien akan melakukannya sendiri.

Sesi ke empat: Psikoedukasi keluarga. Memberikan penjelasan pada keluarga klien tentang keadaan klien dan apa yang harus orang tua klien lakukan. Penjelasan yang diberikan kepada kedua orang tua klien dijelaskan dengan konkret dan menggunakan contoh agar bisa dengan mudah dipahami. Karena keterbatasan ibu klien dalam memahami, terapis sepenuhnya menjelaskan kepada ayah klien kondisi klien, mengapa hal tersebut dapat terjadi, kenapa harus dilakukan terapi, dan apa yang harus dilakukan sebagai orang tua secara konkret, kemudian ayah klien menjelaskan kembali kepada ibu klien hingga ibu klien mengerti.

Sesi ke lima: Homework Assigment. Merancang jadwal aktivitas yang akan klien lakukan sehari-hari sesuai target yang diinginkan yaitu mandi sendiri, makan sendiri, berpakaian sendiri selama 1 minggu kedepan. Jika klien mampu melakukan akan diberikan penguatan yang akan diawasi oleh kedua orang tua klien. jadwal yang dirancang bersaman terdiri dalam bentuk gambar yang akan dicentang oleh orang tua klien jika klien mampu melakukannya, dan mencetang penguatan apa yang diberikan oleh orang tua klien yaitu pujian atau diberikan uang jajan, pemberian penguatan ditentukan sendiri oleh orang tua klien dan klien.

Sesi ke enam: Evaluasi dan terminasi. Melakukan evaluasi terhadap tugas dan aktivitas yang telah dilakukan klien pada seminggu yang lalu. Setelah itu menyimpulkan hal-hal yang telah dipelajari klien selama proses intervensi agar klien dan orang tua klien mau membiasakan diri dan melanjutkan untuk melakukan aktivitas yang telah dilakukan selama beberapa hari. Meminta dan mengingatkan keluarga untuk tetap mengontrol klien meskipun proses intervensi telah selesai. Dalam sesi evaluasi ini diketahui bahwa klien lebih sering mendapatkan pujian karena sudah mampu mandi sendiri walaupun masih harus diingatkan, pada hari ke-1 hingga hari ke-3 masih memunculkan perilaku bahwa klien masih mengharapkan dibantu oleh kedua orang tuanya, namun terlihat di hari ke-4 hingga ke-7 klien sudah mampu konsisten melakukan target yang ditentukan dengan mendapatkan pujian serta jajan dari kedua orang tuanya.

Sesi ke tujuh: Follow up. Sesi selanjutnya yaitu melakukan follow up, yaitu untuk melihat sejauh mana perkembangan klien dengan intervensi yang diberikan, dengan menanyakan kendala atau kesulitan klien saat melakukan intervensi. 2 minggu setelah intervensi diberikan terapis melihat kembali kondisi klien, terlihat klien sudah mampu mandi dan berpakaian sendiri saat, klien juga berangkat mengaji sendiri tanpa minta diantarkan. Ayah klien terlihat mengelus kepala klien dan memberikan jempol tanda bahwa ayah klien memberikan pujian kepada klien dan juga memberikan uang jajan. Klien bercerita bahwa klien sangat senang karena ayah klien selalu membantunya belajar walaupun menurut ayah klien, klien belum banyak menunjukan kemajuan dalam belajar. 


\section{Hasil dan Pembahasan}

\section{Hasil}

Intervensi pada awal kegiatan membentuk rapport dengan klien agar klien mau mengikuti instruksi maupun kepercayaan yang ada, dengan cara mengajak klien bermain bersama dan mengajak klien menceritakan kegiatan sehari-harinya. Langkah kedua dengan memberitahukan kontrak kegiatan dengan orang tua klien akan diadakannya terapi yang membutuhkan peran orang sebagai soulusi atas permasalahan yang klien hadapi dan juga dikeluhkan oleh orang tua klien dengan menjelaskan secara kongkret prosedur yang akan diberikan pada klien dan manfaat terapi yang akan diberikan.

Pemberian psikoedukasi kepada kedua orang tua klien juga dilakukan, psikoedukasi yang diberikan berupa penjelasan mengenai keadaan klien dan apa yang harus kedua orang tua klien lakukan untuk menghadapi klien. Kedua orang klien mengakui bahwa klien masih belum bisa mandiri dalam melakukan kegiatan yang bersifat otonom, dan harus dibujuk berulang kali hingga klien mau melakukannya.

Keterampilan-keterampilan bantu diri, kemandirian dan juga kesadaran diberikan kepada klien agar dapat mengembangkan kemampuannya sesuai dengan usia klien meliputi mandi, makan dan berpakaian. Intervensi ini dilakukan kedua orang tua klien dengan menjelaskan apa yang akan klien dapatkan penguatan saat dapat melakukan hal tersebut. Kegiatan yang dilakukan selama 1 minggu ini menunjukan hasil bahwa pada awalnya klien masih harus dibujuk saat mandi, berpakaian dan makan yang diambilkan serta disuapi. Namun setelah beberapa hari klien sudah mau mandi sendiri tanpa dibujuk seperti sore klien langsung mandi karena akan pergi mengaji tanpa dibujuk dan dimandikan ibu klien, klien juga memilih sendiri baju yang akan klien gunakan ke tempat mengaji.

Dari hasil evaluasi keterampilan yang klien munculkan ditunjang dengan pemberian penguatan agar perilaku tersebut terus terulang, klien mulai mengerti jika klien mandi dan berpakaian sendiri akan diberikan uang jajan sehingga terjadi peningkatan di setiap harinya, pada follow up juga terlihat klien tetap konsisten, sebagaimana ditunjukkan pada Gambar 1.

Dalam self report kemandirian yang diberikan ada 6 kegiatan yang diharapkan dapat klien lakukan sendiri dalam sehari untuk mencapai target, berdasarkan grafik kemandirian yang ada diketahui bahwa kegiatan klien dalam target makan sendiri terlihat pada hari ke-1 dan ke-2 tidak ada yang klien lakukan sendiri namun, di hari ke-3 klien mau melakukan walaupun hanya 1 kali dalam sehari, kemudian terlihat perubahan pada hari ke-4 hingga ke-7 yaitu klien mulai konsisten untuk makan sendiri.

Pada target mandi yang harus klien lakukan sendiri klien diketahui bahwa pada hari-1 klien hanya melakukannya sebanyak 1 kali, terjadi peningkatan pada hari ke-2 namun pada hari ke-3 dan ke-4 terjadi penurunan, walaupun begitu pada hari ke-5 terjadi peningkatan kembali dan konsisten hingga hari ke-7. Pada target terakhir yaitu berpakaian pada hari ke-1 hingga ke-3 klien konsisten melakukan tugasnya walaupun hanya sekali dalam sehari, kemudian pada hari ke-4 terjadi peningkatan yang konsisten hingga hari ke-7.

Ayah klien memberikan pujian kepada klien karena mau mandi sendiri walaupun masih diingatkan, memberikan jajan saat klien mau melakukan tanpa harus diingatkan, ayah klien lebih sering memberikan pujian kepada klien dibandingkan memberikan jajan kepada klien. Secara tidak langsung klien mulai membentuk pola keterampilan dirinya sendiri untuk dapat lebih mandiri dan tidak bergantung pada kedua orang tuanya. Penjelasan lebih singkat dapat dilihat pada Tabel 1 


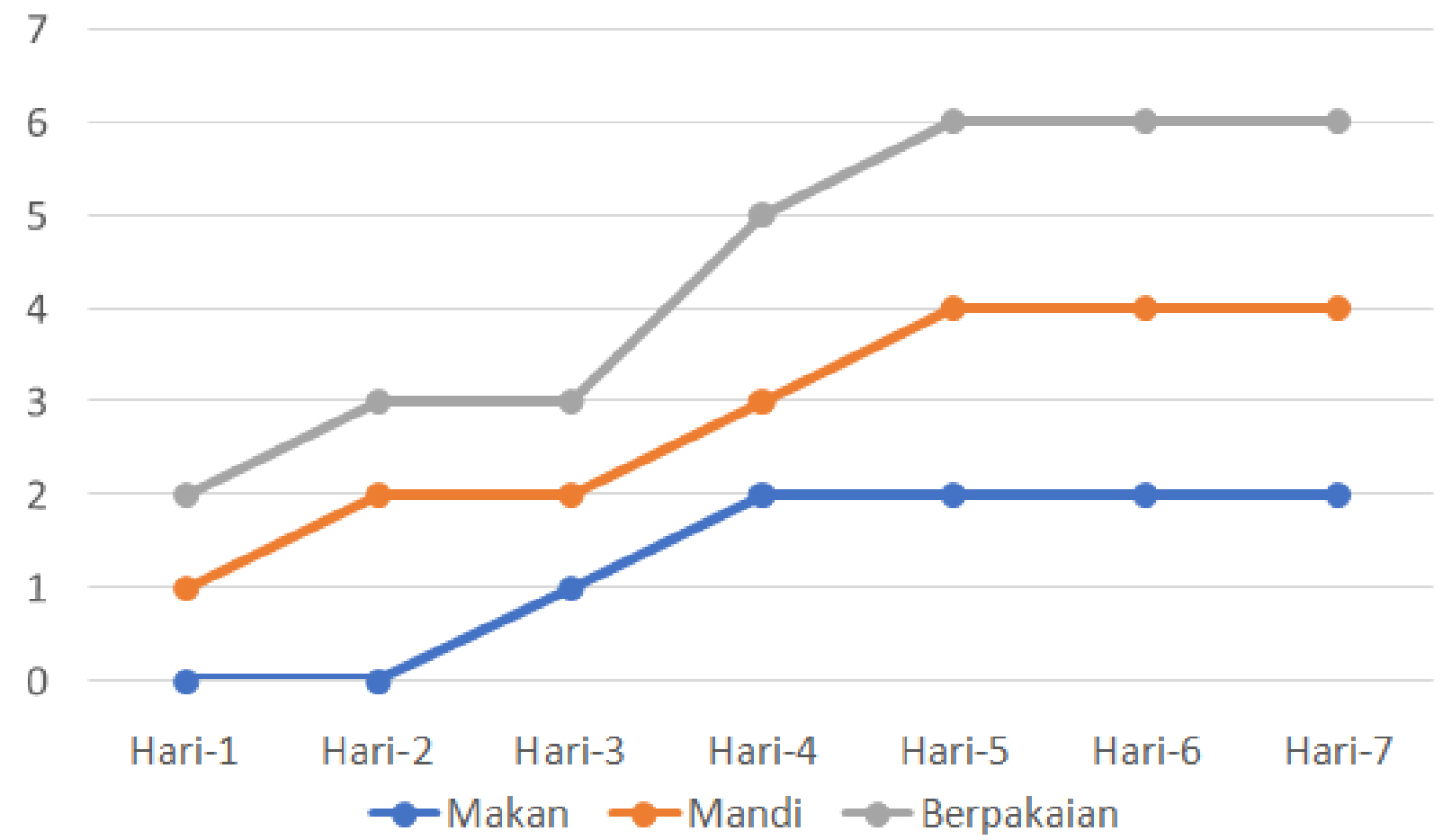

Gambar 1. Kemajuan Kemandirian pada subjek.

\section{Pembahasan}

Intervensi dalam bentuk behavior dilakukan disesuaikan dengan kondisi klien, yaitu klien memiliki kapasitas intelektual yang rendah karena fungsi kognitif tidak berkembang sesuai dengan usianya saat ini, terlihat dari perilaku, dan cara berbicaranya. Klien cenderung kesulitan dalam menyelesaikan masalah karena pemahaman konsep serta kemampuan konsentrasinya sangat kurang, klien hanya dapat memahami lingkungan dalam pengertian yang konkret. Hal ini disebabkan karena klien kurang mendapatkan rangsangan ataupun stimulus dari lingkungan terutama dari ayah dan ibu klien, sehingga klien kurang memiliki keterampilan-keterampilan yang seharusnya sudah menjadi kebiasaan klien.

Klien memiliki kapasitas intelektual (IQ $=64$ ) menurut DSM V nilai IQ sebesar ini termasuk dalam kategori retardasi mental ringan, dengan keterbatasan intelektual yang dimiliki klien, klien mengalami kesulitan dalam akademik, mempelajari hal-hal baru, terutama yang membutuhkan konsentrasi dan daya ingatan, karena klien berpikir secara konkret dan sederhana. Untuk itu terapi behavior dengan teknik penguatan positif atau penguatan positif diberikan kepada klien.

Terapi behavior yang digunakan menyertakan penerapan yang sistematis dan prinsip-pinsip belajar pada perubahan tingkah laku ke arah cara-cara yang lebih adaptif, salah satunya yaitu dengan menggunakan teknik penguatan positif. Teknik penguatan positif adalah pembentukan suatu pola tingkah laku dengan memberikan penguat atau penguatan positif segera setelah tingkah laku yang diharapkan muncul adalah suatu cara yang ampuh untuk mengubah tingkah laku (Corey, 2013). Perilaku yang diinginakan muncul pada klien yaitu mandi, makan, berpakaian dan juga keinginan untuk belajar dari yang awalnya tergantung pada ibu klien untuk melakukan hal tersebut, klien mulai perlahan-lahan melakukannya sendiri atas kesadaran diri sendiri.

Penguatan positif dilakukan dengan memberikan penguatan yang menyenangkan bagi anak setelah tingkah laku yang diharapkan muncul dengan tujuan tingkah laku yang diinginkan akan 
Tabel 1. Sebelum dan Sesudah Intervensi Kemandirian

\begin{tabular}{|c|c|c|}
\hline No. & Sebelum Intervensi & Sesudah Intervensi \\
\hline 1 & $\begin{array}{l}\text { Dimandikan ibu, tidak mau mandi } \\
\text { sendiri }\end{array}$ & Mandi sendiri namun masih diawasi \\
\hline 2 & Diambilkan makanan dan disuapi & $\begin{array}{l}\text { Mengambil peralatan makan sendiri } \\
\text { dan makan sendiri }\end{array}$ \\
\hline 3 & Baju diambilkan & Memilih dan mengambil baju sendiri \\
\hline 4 & Baju dan sepatu dipakaikan ibu & Memakai baju dan sepatu sendiri \\
\hline 5 & Minta disisirkan ibu & Sisir rambut sendiri setelah mandi \\
\hline 6 & Dipaksa pergi mengaji & Pergi mengaji tanpa dibujuk \\
\hline 7 & Diantar ke tempat mengaji & Pergi ke tempat mengaji sendiri \\
\hline 8 & Marah dan menangis minta jajan & $\begin{array}{l}\text { Mandi sendiri atau mengerjakan pr } \\
\text { agar diberikan jajan oleh ayah }\end{array}$ \\
\hline 9 & $\begin{array}{l}\text { Tidak mau belajar dan mengerjakan } \\
\text { pekerjaan rumah dari sekolah }\end{array}$ & $\begin{array}{l}\text { Mau belajar dan mengerjakan } \\
\text { pekerjaan rumah dari sekolah bersama } \\
\text { ayah agar diberikan jajan }\end{array}$ \\
\hline
\end{tabular}

diulang kembali (Corey, 2013). Menurut Skinner (Priatna, 2012) tingkah laku organisme dapat dikontrol melalui pemberian penguatan yang tepat dalam lingkungan. Skinner mengemukakan bahwa setiap memperoleh stimulus, maka seseorang akan memberikan respons berdasarkan hubungan S-R. Respons yang diberikan ini dapat sesuai (benar) atau tidak sesuai (salah) dengan apa yang diharapkan. Respons yang benar perlu diberi Penguatan agar orang tersebut ingin melakukannya kembali. Skinner (Alwisol, 2009) menerangkan penguatan merupakan suatu strategi kegiatan yang membuat perilaku tertentu berpeluang untuk terjadi atau sebaliknya (berpeluang untuk tidak terjadi lagi) pada masa yang akan datang.

Penguatan positif yang diberikan pada klien berupa pujian yang segera diberikan jika klien mampu melakukan, dan terkadang ayah klien memberikan jajan tambahan kepada klien agar nanti klien mengulangi tingkah lakunya. Pemberian penguatan berupa jajan kepada klien setelah klien memunculkan tingkah laku dikenal dengan primary reinfocer yaitu penguatan yang dapat langsung klien nikmati dalam bentuk makanan atau minuman. Sedangkan pemberian penguatan dalam bentuk pujian yang diberikan kepada klien saat klien mampu mandi sendiri tanpa diingatkan merupakan bentuk secondary reinforcer, sedangkan ketika klien ingin bermain setelah pulang sekolah klien diingatkan untuk mengganti pakaian sendiri terlebih dahulu kemudian klien diperbolehkan untuk bermain yang disebut dengan contingency reinforcer yaitu penguatan yang berbentuk syarat agar anak mau memunculkan tingkah laku atau respon yang diinginkan (Wilis, 2007).

Skinner (Seifert, 2010) membedakan adanya dua macam respons, respondent response (reflexive response), yaitu respon yang ditimbulkan oleh rangsangan tertentu yang disebut eliciting stimuli, menimbulkan respon-respon yang secara relatif tetap. Respon yang kedua yaitu operant responsen (instrumental response), yaitu respon yang timbul dan berkembang diikuti oleh rangsangan tertentu yang disebut reinforcing stimuli atau reinforcer, karena rangsangan tersebut memperkuat respons yang telah dilakukan oleh organisme. Jadi, rangsangan mengikuti (dan karenanya memperkuat) sesuatu tingkah laku tertentu yang telah dilakukan. Seperti yang terjadi pada klien jika klien mampu melakukan aktivitas bersih diri sendiri maka klien akan medapatkan pujian maupun jajan dan akan semikin membuat klien untuk terus melakukan hal tersebut.

Dalam pengkondisian operant, stimulus-stimulus tertentu bisa mempengaruhi kemungkinan munculnya respon operant, tanpa harus menjadi penyebab munculnya respon tersebut (Seifert, 
2010). Dalam pengkondisian operant, perilaku yang meningkatkan frekuensinya seringkali disebut dengan operant, hal ini disebabkan karena perilaku tersebut "mengoperasikan" atau dalam kata lain menghasilkan, konsekuensinya (Seifert, 2010). Dengan kata lain operant adalah perilaku yang diperkuat jika akibatnya menyenangkan.

Hasil dari pengkondisian tersebut dapat meningkatkan keterampilan serta kemandirian yang dimiliki oleh klien, sesuai tingkat usianya dan keberfungsian motorik yang ada pada klien. Kemandirian adalah perilaku yang aktiftasnya diarahkan kepada diri sendiri, tidak mengharapkan pengarahan dari orang lain (Soemantri, 2007). Kemandirian dalam mengurus diri dan kemandirian dalam menghasilkan keterampilan yang sesuai dengan kemampuannya, memiliki kepercayaan diri sehingga tidak lagi membutuhkan bantuan orang lain. Dengan keadaan kondisi klien yang memiliki intelektual disabiltas kemandirian yang diharapkan adalah dapat mengurus diri sendiri dan bertanggung jawab yang akan berdampak pada perkembangan selanjutnya.

\section{Simpulan}

Terapi behavior dengan teknik penguatan positif dapat membantu klien dengan intelektual disabilitas (ID) untuk memunculkan tingkah laku baru secara terus menerus, hal ini membuat klien mampu melakukannya tanpa bergantung pada kedua orang tua klien walaupun masih perlu mendapatkan pengawasan. Kedua orang tua klien juga menjadi lebih memahami dan sadar tentang keadaan anak mereka dan bagaimana harus bersikap kepada klien agar klien mampu memunculkan tingkah laku yang diinginkan muncul. Stimulus dari kedua orang tua menjadi hal yang penting bagi klien dalam mewujudkan target yang kongkrit dan realistis sesuai dengan keadaan klien memudahkan klien.

Berdasarkan asesmen dan intervensi yang dilakukan berikut beberapa saran yang dapat direkomendasikan kepada klien dan keluarga agar tetap dapat melakukan keterampilan atau perilaku baru yang telah klien miliki dan untuk keluarga klien untuk tetap mendorong dan memberikan motivasi kepada klien agar klien konsisten dalam melakukan keterampilan baru yang telah klien miliki menjadi kebiasaan sehari-hari. Diharapkan ayah klien tetap dapat meluangkan waktu untuk dapat menemani klien belajar, dan ibu klien dapat mengarahkan klien untuk tetap mandiri dan tidak lagi memanjakan klien.

\section{Referensi}

Albrecht, G.L., Seelman, K.D., \& Bury, M. (2001). Handbook of disability dtudies. London: Sage Publication, Inc.

Alwisol. (2009). Psikologi keprinbadian. Malang: UMM Press.

American Psychiatric Association. (2013). Diagnostic and statistial manual (5th ed.) Washington, DC: American Psychiatric Publishing.

Borkowski, J.G., Carothers, S.S., Howard, K., Schatz, J., \& Farris J.R., (2007). Intellectual assessment and intellectual disability. In J. W. Jacobson, J. A. Mulick, \& J. Rojahn (Eds.), Handbook Of Intellectual And Developmental Disabilities (pp. 261-277). New York: Springer Science \& Business Media. doi: 10.1007/0-387-32931-5_14

Chaplin, C. (1993). Kamus lengkap psikologi. Jakarta: PT. Raya Grafindo Persada.

Corey, G. (1999). Teori dan praktek "konseling dan psikoterapi". Refika Aditama. Bandung.

Corey, G. (2013). Teori dan praktek konseling \& sikoterapi. Terjemah E. Koswara. Bandung: Refika Aditama.

Feist, J., Feist, G. (2009). Theories of personality (7th edition). New York: McGrawHill.

Ishartiwi. (2010). Identifikasi bentuk intervensi pembelajaran dan perilaku belajar anak retardasi mental. Juranl Penelitian Ilmu Pendidikan vol 03, No 1.

Komalasari., \& Gantina. (2011). Teori dan teknik konseling. Jakarta: PT. Indeks.

Kristen, M. (2015). Behavioral interventions for individuals with intellectual disabilities exhibiting automatically reinforced challenging behavior: stereotypy and self-injury visiting assistant professor. Psychology Central Connecticut State University, New Britain, CT, USA.

Langthorne, P., \& McGill, P. (2009). A tutorial on the concept of the motivating operation and its importance to application. Behavior Analysis in Practice 2: 22-31. 
Latipun. (2015). Psikologi konseling. Malang. UMM Press.

Maramis, W.F., \& Maramis, A.A. (2009). Catatan llmu kedokteran jiwa edisi 2. Surabaya: Airlangga University Press.

Priatna, T. (2012). Etika pendidikan. Bandung: CV Pustaka Setia.

Saputro, I.P. (2014). Pola pengembangan lembaga untuk mengembangkan motensi dan fungsi sosial snak tunagrahita di SLB-C Khirsna Murti Jakarta. Jurnal Penelitian Kesejahteraan Sosial.

Seifert, K. (2010). Manajemen pembelajaran dan intruksi pendidikan; Manajemen Mutu Psikologi Pendidikan Para Pendidik. terj. Yusuf Anas. IRCiSoD. Yogyakarta.

Sularyo., \& Sunarwati, T. (2000). Retardasi mental. Sari Pediatri vol 2:3.

Supriyono., \& Yoyon. (2010). Peran terapi perilaku dengan menggunakan penguatan positif terhadap orang dewasa yang mengalami retardasi mental. Jurnal Psikologi: Universitas Brawijaya Malang.

Willis, S. (2007). Konseling Individual. Bandung: Alfabeta. 